\title{
Writing the Lives of Dissent: Life Writing, Religion and Community from Edmund Calamy to Elizabeth Gaskell
}

\section{Felicity James}

Department of English, University of Leicester, Leicester, UK

Department of English, School of Arts, University of Leicester, Leicester, LE1 7RH, fj21@1e.ac.uk.

Felicity James is a lecturer in eighteenth- and nineteenth-century literature in the Department of English at the University of Leicester. She works on sociability, friendship and creative exchange amongst writers and communities, with a specific interest in the literature and networks of religious Dissent. She has published on Romantic friendship circles (Charles Lamb, Coleridge and Wordsworth: Reading Friendship in the 1790s (2008)) and families (Religious Dissent and the Aikin-Barbauld Circle, 1740-1860, co-edited with Ian Inkster (Cambridge: Cambridge University Press, 2011) and is currently editing the collaborative children's writing of Charles and Mary Lamb for Oxford University Press. 


\title{
Writing the Lives of Dissent: Life Writing, Religion and Community from Edmund Calamy to Elizabeth Gaskell
}

\author{
This essay explores the collaborative life writing of communities across time: \\ specifically, the disparate, questioning, quarrelsome religious groupings of \\ Rational Dissent as Unitarianism gradually emerged as a separate sect at the turn \\ of the nineteenth century. It focusses on three moments of life writing in different \\ genres by Rational Dissenters: sermons by Theophilus Lindsey, a memoir by his \\ wife Hannah Lindsey, and the novel North and South by Elizabeth Gaskell. \\ Moving across genre and century, it analyses the ways in which a Unitarian \\ identity evolved through the nineteenth century, and asks how individuals \\ constructed their own religious identity while also participating in a larger \\ Dissenting tradition. Lacking a unifying creed, and with its adherents often \\ professing different and sometimes contradictory theological beliefs, \\ Unitarianism is not easy to define or describe. Yet this is precisely why group \\ historiography and collective biographies become important: Rational Dissenters \\ come to rely on shared allusions and narratives to bind them together, such as the \\ memory of Black Bartholomew's Day, the Great Ejection of 1662. The essay \\ traces such allusions through the eighteenth and nineteenth centuries to explore \\ the enduring collective concerns of a community - and to show how, in the hands \\ of Gaskell, these might make their way into a larger literary dialogue.
}

Keywords: religion; dissent; community; Gaskell

In this special issue we have looked at examples of life writing which push across boundaries of genre, space, and time in different ways: writing the life of a city through its maps and guides; reconstructing family narratives across generations; exploring the inner dialogue of a marriage, a sibling relationship, a creative circle. In this article, I reconstruct the life of a specific, if loosely bound, community - the disparate, questioning, quarrelsome religious groupings of Rational Dissent as Unitarianism gradually emerged as a separate sect at the turn of the nineteenth century. Like the friendship circles explored by Julian North elsewhere in this volume, such communities, 
although not literary coteries, similarly relied on the language of allusion and shared readings. North describes a form of 'intertextual sociability' working across time: similarly, these worshippers created, exchanged, and changed collective memories in an attempt to define the particularities of their own religious affiliations.

But the Rational Dissenters' attempt at self-definition was, and remains, a struggle. There is little critical consensus even today as to how the term should be employed. 'Properly speaking,' writes Knud Haakonssen, 'Rational Dissent meant the rejection of Calvinism and the denial of the necessity of spiritual regeneration'; Haakonssen himself, however, editing a book on the topic, comes to feel that 'Enlightened Dissent' better captures the complexity of the issue as 'a broadly based rational religion characterised by a determination to combine reason and faith and by a will to tolerate different ways of doing so' (Haakonssen 4, 5). As such it could attract different allegiances, sometimes within a single congregation: the term could encompass Presbyterian, Baptist, Arian and Socinian viewpoints. What united such disparate worshippers was their divergence from established Anglican practice and thus their inability to subscribe to the Thirty Nine Articles of the Church of England. Baptists, for example, believed that infant baptism was not taught anywhere in the Bible and thus rejected it; another strand of Rational Dissenters, who came to be known as 'Unitarian' in the early nineteenth century, denied the Trinity, seeing God as one entity and Christ as human rather than divine. Such denial of the Trinity was in fact illegal and would remain so until the Blasphemy Act of 1698 was finally repealed in 1813; furthermore, it was not until 1828 that the Test and Corporation Acts, which excluded Dissenters from holding public office, were repealed. ${ }^{1}$ The knowledge of such laws helped foster allegiances between Rational Dissenters despite different theological viewpoints: they were also sustained by a common insistence on the importance of 
individual interpretation of the scriptures. Belief must be based on one's own reading, and not on blind adherence to traditional practice:

As the servants of God, and disciples of Christ, we can only submit to the authority of Christ in his written word; and in the sense we ourselves put upon it, and not that of another. (Lindsey Sermon 10)

This exemplary statement of Dissent comes from the sermon preached at the opening of the Essex Street Chapel by Theophilus Lindsey in 1774. Lindsey was a prominent Anglican clergyman who seceded in late 1773 after experiencing doubts over the Trinity, and frustration at ongoing divisions between the Church of England and Protestant Dissent: in 1772, inspired by his father-in-law Francis Blackburne's latitudinarian thinking, he had helped organise a Parliamentary petition to abolish compulsory subscription to the Thirty Nine Articles. On its rejection, he joined forces with Dissenters of longer standing such as Joseph Priestley to form the Essex Street Chapel, a meeting point for different, rational approaches to religion, as, suggested Lindsey, had been the practice in early Christianity: 'all professing to follow the same rule of holy scripture; but following it in different ways according to their own apprehensions' (14). For congregations like Essex Street, there was no creed. 'No one is to dictate with authority to another' (8), preached Lindsey, since the authority respected above all was that of the individual's intellectual enquiry.

The Dissenters' rejection of authority thus creates intriguing parallels with the theories of intertextuality which have been a repeated theme in this special issue, principally Barthes' repudiation of 'a single "theological" meaning (the "message" of the Author-God)', and his characterisation, instead, of text as 'multidimensional space' where multiple readers and readings might exist simultaneously (Barthes 126). Dissenters strive to create a group identity for themselves based, paradoxically, on 
divergence, on their rejection of 'a single "theological" meaning': in order to do so, however, they rely on shared reading and writing, on the creation and repetition of key moments. In the words of John Seed, to whose subtle and interesting readings of the historiography of Dissent I am indebted, 'it was through the narratives it told about itself that a fluid and unstable historical community called 'the Dissenters' was produced and reproduced during the eighteenth century' (Seed 8). Such narratives are at once necessary to create group identity, but also - particularly given the nature of Dissent - subject to revision and rewriting, and it is in the differences and difficulties between such narratives that some of the most interesting insights might come.

In this article, I want to examine some Dissenting narratives in which we can see individuals both exploring their own religious approach and participating in a larger community narrative. My central case study comes from Theophilus Lindsey himself, whose crisis of faith is recorded in his Apology [...] on Resigning the Vicarage of Catterick, informed by a much older text of Dissent, Edmund Calamy's account of the Great Ejection of 1662, when a large body of nonconformists were expelled from the Church of England. Lindsey's attempts to structure and narrate his religious experience are then rewritten by other members of the Dissenting community, as in my second example, from 1808: a manuscript contained in a box of archival material in Harris Manchester College, Oxford. Along with sermons by Lindsey and Lindsey's friend William Chambers, Rector of Thorpe Abchurch, Northamptonshire, MS. Lindsey 2 contains a small handwritten account of the early life of Theophilus Lindsey by his wife Hannah, and a brief narrative of the foundation of Essex Street. My third and final example is a Victorian novel, North and South (1855). Elizabeth Gaskell's story of Mr Hale, who secedes from the Church of England and is forced to leave his idyllic country parish in the South for a Dissenting city in the industrial heartlands is a reworking of 
Lindsey's earlier narrative and a statement of Gaskell's own Unitarian faith. Each piece - sermon, manuscript, novel - might be viewed as an example of Dissenting life writing; each might also be seen as writing the life of Dissent itself, since they all reflect on the longer history of Unitarianism, showing us how the same story of Lindsey's secession might be retold, reshaped, and presented for slightly different purposes.

The story of modern Unitarianism begins with a forward-looking call to unity, issued on the 17 April 1774, in a disused auction-room on Essex Street, just off the Strand. Outside, reported its ardent supporter, the lawyer John Lee, there were 'about ten coaches at the door', giving the proceedings a pleasing 'degree of respectableness' (Belsham 70). Inside, a diverse group had gathered to hear Lindsey preach: MPs, business men, disgruntled Anglicans, powerful men such as Lord Despenser, intellectuals such as Benjamin Franklin and Joseph Priestley, the publisher Joseph Johnson, as well as interested onlookers, such as a lady's maid who had heard that 'a gentleman was going to open a room, to preach a new religion' (Cappe 176). Lindsey’s opening sermon, which took as its motto a phrase from Ephesians iv.3, 'Endeavouring to keep the unity of the Spirit in the bond of peace', brought together the theme of unity between differing groups with the argument for divine unity. The 'One body' of Christian fellowship, in which 'No one is to dictate with authority to another', was 'under the direction of One Spirit, one rule of faith, and one Lord Jesus Christ'; Christ himself was shown as 'subordinate to, and receiving all his powers from the One God and Father of all' (8). Although the word 'Unitarian' was not mentioned directly in the sermon, this chapel was, as Lindsey was later to recall, the 'first established on professedly unitarian principles...' (Lindsey Discourse 4). Other Dissenting chapels with Unitarian affiliations, such as the Octagon Chapel, Norwich, or Cross Street Chapel, Manchester, had slowly made their way from Presbyterianism or Baptism; this 
was the first establishment set up with the intention of 'worship being directed and confined to the one God and Father of the universe, exclusively of all other persons or beings' (4), and was also designed to win over those who still yearned for reform within the Church of England.

But for all this emphasis on unity, conciliation, and 'respectableness', there was a darker narrative at work, of persecution and difference. Through the opening sermon run reminders that the history of the previous century was constantly present for Dissenters illegally denying the Trinity. 'Not a few amongst us,' warned Lindsey, 'lye undeservedly under the terror of severe, unjust, penal laws, made in bad and dark times' (20). Although he went on in optimistic Enlightenment tone to point out that 'these laws sleep,' and to look forward to an ever-increasing climate of tolerance, 'the growing enlightened spirit of the nation' (20), it is clear that his narrative of progress and unity is undercut by anxiety. This becomes still clearer when presenting his account of his own secession, when we see that he was consciously following an older strand of collective biography belonging to the 'bad and dark times' of Dissenting persecution, and aligning his self-imposed ejection from his living at Catterick with the Great Ejection of Bartholomew Day, 24 August 1662. This was an emblematic day for Dissent; when, in Richard Baxter's words, 'about One thousand eight hundred, or Two thousand Ministers were Silenced and Cast out' (Baxter II; 385). Often remembered by Nonconformists as 'Black Bartholomew Day', the event 'played a part in fashioning their distinctive denominational consciousness', lingering 'as the memory of a great wrong,' to quote A. G. Matthews, 'which those of later generations had vicariously suffered in the persons of their forefathers, the martyrs and confessors of 1662' (Matthews xvi), and giving rise to a particular 'Bartholomean oeuvre' of valediction, justification and remembrance (Appleby 5). This 'memory of a great wrong' was taken on by Lindsey and used to 
establish a Dissenting lineage for himself. Although he himself was born into a world of family connection, he came to identify with an earlier generation of Dissenters, and to link himself intellectually with those suffering forefathers.

The clearest way he does this is through his reading of and allusion to an earlier text of Dissent. In his biography of Lindsey, Thomas Belsham tells us that he 'fortified his mind by reading Calamy's Account of the Ministers who were ejected for Nonconformity in the year 1662, and by collecting materials for a history of persons who had suffered for their profession of Unitarian principles' (Belsham 67). This reading matter was a very specific choice: Lindsey was self-consciously participating - and intervening - in an important strand of Dissenting historiography. The 'Account... of those Worthy Ministers who were ejected, after the Restauration of King Charles the Second' was published in 1702 by Edmund Calamy the third, as the ninth chapter of his Abridgment of Mr Baxter's History of his Life and Times. It continued and extended the commitment to overt Dissent shown by the descendants of Edmund Calamy the Elder, the first nonconformist to be subject to the penalty of the Act of Uniformity, and an important emblem of the Dissenting cause. 'Writers took up Calamy's case,' as Sharon Achinstein has explored, 'as a means to discuss the nature and scope of community' (Achinstein 3). His emblematic significance was furthered by his son and grandson, who kept alive the idea of his sacrifices. His son, also called Edmund Calamy (16341685) was similarly ejected from his ministry in 1662, and although never imprisoned, persecuted for his beliefs, 'forced to disguise himself and skulk in private holes and corners, and frequently change his lodgings' (Calamy Own Life I, 88). It was the third Edmund Calamy (1671-1732), who followed father and grandfather in becoming a Presbyterian minister, who worked to secure the memory of the Calamy contribution to Dissent, by commemorating the stories of the preceding generations. 
His account of the ejected ministers was not just a list, but also a collection of biographies, since, as he explains, 'Lives and Characters are very Entertaining' (Baxter and Calamy II, vii). This, in itself, is an interesting comment, with its suggestion that Calamy is thinking about the work as both an act of homage and commemoration, but also as an engaging reading experience which might evoke sympathy and interest. Indeed, his narratives, gathered from 'the printed Lives, and scatter'd Characters, and Funeral Sermons' of the ministers, and accounts 'communicated to me by divers Friends in City and Country', have a lively, occasionally humorous aspect, calling attention to personal characteristics and quirky biographical detail. Typical is the account with which the book begins, that of Simeon Ash, for instance, included even though he was buried 'the very even of Bartholomew-day', which describes his 'Primitive Simplicity', characterised by 'a Chearful Mind' and a 'cheerful Exercise of Faith' (Baxter and Calamy I, 1). Other ministers, such as John Oldfield, are allowed to speak in their own words, in extracts from a manuscript which Calamy says 'manifest[s] the seriousness and solemnity of his Spirit' as he considers his position in 1662: 'thou canst no longer continue in thy work,' he reflects to himself, 'without dishonour to God, discredit to religion, foregoing thy integrity, wounding conscience, spoiling thy peace, and hazarding the loss of thy salvation'. Oldfield fights out his position, struggling with his doubts and uncertainties, defending his decision to leave his Church: in turn, Calamy uses this private 'soliloquy' to create a public rallying point for Dissent, which, as we will see, is picked up by later Dissenters, Lindsey and Gaskell. Calamy's is a collective biography of Dissent, not only in terms of gathering together individual histories of these 'Good Men' and their trials and persecutions from diverse sources, but also using them first to construct a sense of an exemplary Dissenting life, and, secondly, to create a sense of Dissenting identity through historical narrative. Indeed, Calamy's History is 
one of the texts John Seed selects as having particular cultural power, deeply significant in terms of the common identity Dissent, in all its various guises, was attempting to forge for itself through the eighteenth century, and as such fought over, contested, and disputed.

It is this larger narrative of Dissent which Lindsey is joining, and shaping, when he invokes Calamy. Reading the book with a special sense of identification, he was deeply moved, as he told William Turner in 1772:

I never was more affected with any book than with Calamy's History of those worthy confessors that gave up all in the cause of Christ, and for a good conscience, at the Restoration. No time or country ever did furnish at once such a list of Christian heroes; and I fear our own country now would fall far short of furnishing such a large number upon a like trying occasion. But it was the effect of their Puritan education. They had learned to fear God from their youth, and to fear nothing else. (Belsham 68)

His own narrative of his crisis of conscience, The Apology, contains descriptions of figures important to Anti-Trinitarianism such as Thomas Emlyn, William Whiston, and Samuel Clarke, in which Lindsey, like Calamy, emphasises their simplicity of character and their personal courage. He then inscribes himself among them, devoting chapter six to an account of his own doubts. The opening sentence of the chapter evokes his praise of Calamy's subjects, who had 'learned to fear God from their youth, and to fear nothing else' (Belsham 68). Lindsey writes: 'I was impressed from early youth with a love of truth and virtue, a fear of God, and a desire to approve myself to him' (Apology 202). From the start, then, his own experience of doubt and secession is structured by the experiences of Calamy's subjects, and this link is made explicit in a later footnote. Referring to his early reluctance to leave the church when first experiencing doubts over the Trinity he berates his younger self for not having followed the "plain road of duty 
and uprightness'. This is footnoted with a reference to the manuscript by Oldfield quoted by Calamy:

Says one of the ejected ministers, after the restoration in 1660, Mr. Oldfield, of Carsington, Derbyshire, in his private MS. soliloquy and deliberation with himself, which fell into Dr. Calamy's hands; 'When thou canst no longer continue in thy work, without dishonour to God, discredit to religion, foregoing thy integrity, wounding conscience, spoiling thy peace, and hazarding the loss of thy salvation; in a word, when the conditions upon which thou must continue (if thou wilt continue) in thy employments are sinful, and unwarranted by the word of God; thou mayest, yea, thou must believe, that God will turn thy very silence, suspension, deprivation, and laying aside, to his glory and the advancement of the gospel's interest. (Apology 206)

At the end of this excerpt, Lindsey adds a note about its source, from

Calamy's Account (vol. ii. p. 175) of ministers who suffered themselves to be ejected and silenced, to the number of two thousand [...] a long list, that does honour to human nature, and to our own country in particular, which has hitherto taken the lead in the restoration of God's true religion: for Wickliff held up the light to Luther that came after him; and may England still hold it up to the rest of the nations! (Apology 208)

This forms a lengthy footnote, running across three pages, presenting a narrative which underpins Lindsey's own and frames the reader's encounter with this story of secession. It provides the sense of a continuous community across time and difference, creating a lineage which in fact stems from an earlier tradition of Dissent.

The relentless forward movement of Lindsey's narrative, as one generation illuminates the progress of the next - as 'Wickliff held up the light to Luther' nevertheless also contains a backward glance. In setting up Essex Street, Lindsey was establishing a new 'separate congregation, distinct from that of [the] national church.' 
But he is also self-consciously following in a particular tradition, casting himself as one of the Bartholomew Day Dissenters, the exiled, ejected ministers of 1662, and there is a curiously double aspect to this self-presentation. In texts such as the Apology, the narrative of his secession seems constantly, even as it gestures forward to an optimistic, enlightened future for Rational Dissent, to look back doubtfully to a darker history of persecution. Allusions to authors such as Calamy and commemoration of earlier Dissenting experiences such as Bartholomew Day act as a way to structure the present and to unite a community: but they may also, simultaneously, act to unsettle and disturb a collective narrative of progress.

Such unsettling aspects, however, are written out in a subsequent narrative of Lindsey's secession by his wife Hannah. This manuscript is an obituary of Lindsey, written shortly after his death in late 1808 , and its after-life has been as a public document, part of the historiography of Unitarianism in the archives of what was then Manchester College, Oxford. It is an unrevealing piece in some ways, a studied and careful account of Lindsey, which omits mention of conflict or doubt. It covers Lindsey's early years, and describes a trajectory of social mobility, helped along by friendship and family connection. Instead of the alternative lineage of ejected Dissenters Lindsey constructs for himself in the Apology, his wife places him firmly back in a well-connected world of his own family networks, beginning with a description of his father 'the proprietor of [a] Salt works' as 'a man of great integrity and worth', and noting that his mother was 'an excellent pious woman'. Certainly, his mother's family connections helped him greatly: she had lived in the household of Frances, the Countess of Huntington, whose son, Theophilus, $9^{\text {th }}$ Earl of Huntington [1696-1746], stood godfather to Lindsey. Further maternal connections, Lady Ann and Lady Betty Hastings, helped with the young Lindsey's schooling, 'the modest gentle manners of the 
youth having ingratiated him into their favour'. He then went to St. John's College, Cambridge, where he 'availed himself of every advantage which his situation afforded, and took one of the first degrees \& by diligence and an exemplary conduct gain'd the intire approbation of his tutors.' This exemplary conduct had its reward, as Hannah Lindsey narrates it, in friendship, 'when [the tutors] were applied to by the then Chancellor of Lincoln, $\mathrm{D}^{\mathrm{r} .}$ Reynolds to recommend a Chum for his eldest son.' Another important friend was 'young $\mathrm{M}^{\mathrm{r} .}$ Chambers of Derby by whom and his family and their good and most amiable connections our Author was loved and cherished like a brother.' Dr. Chambers, who became Rector of Achurch, remained a close friend, and his sermons are preserved in the box alongside the manuscript. ${ }^{2}$ After a spell as fellow of the college, Lindsey went on to become a deacon in 1746 and a priest the following year. Once again, family connections and friendships, for example with the Earl of Huntington, and the Northumberland family, meant that good livings were assured. He also came into contact with Archdeacon Francis Blackburne - 'Being always a diligent reader of the Scriptures \& inquirer after truth, such minds $c^{d}$ not but unite' - and in 1760, he married Blackburne's daughter Hannah. By 1763, to be closer to his wife's family, he had moved to Catterick in Yorkshire, a living solicited by the Earl of Huntington from George Grenville, secretary of State. Aristocratic connection thus promoted his career, and Hannah Lindsey goes to some trouble to outline the level of personal intimacy her husband enjoyed with his patrons, as in a long note running over pages fourteen and sixteen in the MS, which details the 'kind attention' paid him by the Duchess of Northumberland: indeed, she is moved to comment at the bottom of page 14 that 'this digression is too long'. Much more emphasis is placed on these connections than on his religious development, although on the penultimate page we have a description of Lindsey in Catterick as 
a pattern of a primitive Pastor, instructing the young both of that large Parish, \& the boys of a large Academy in the village, preaching or lecturing twice on a Sunday visiting the sick, admonishing the unwary, superintending schools for the Poor \&c.

That word 'primitive' is the only echo of Calamy and his martyred ministers, who are frequently described as 'Primitive', referring to their contention that the doctrine of the Trinity was a later addition to early Christianity. The secession, such a signal event in the life of both Lindseys, is only mentioned in the very last sentences of this memoir, and again in language which carries only a faint echo of the Bartholomean narrative of ejection and exile Lindsey himself had deployed:

But his scruples increasing as to the only proper object of religious worship no efforts of duty in Church could quiet his mind for acting a part contrary to his convictions for gain, he therefore resigned his Perfarment $[$ sic $]$ and all his worldly support, \& cast himself \& his wife on the Providence of God.

The last phrase, 'cast himself \& his wife on the Providence of God', resonates with the suffering of Calamy's exiled ministers, but there is no elaboration on Lindsey's secession: his reasons, notes Hannah, were given in 'a plain affecting way' in his 'farewell address to his sorrowing flock \& his subsequent works tell the rest'. No mention, here, of Blackburne's disapproval of the step his son-in-law had taken in settling in London; no hint, either, of the tensions involved in the Essex Street venture, or of Hannah Lindsey's own personality and role in her husband's development. She was, as we learn from the letters of Theophilus Lindsey, an expert manager, and responsible for a good deal of the practical organisation of Essex Street, holding firm views, too, on its theological position which would lead to conflict with brother-in-law John Disney. ${ }^{3}$ But such conflicts are outside the scope of this memoir. As Ditchfield notes, it is 'clearly intended for archival preservation', and in presenting her account of 
Lindsey, his wife is taking part in an important Dissenting role, 'archiving, preserving, memorializing' (71-2). The 'memorializing' aspect is emphasised when one realises why it was written. Its publication, which has not been traced before, speaks to the web of family and friendly connections which shaped Unitarianism through the nineteenth century: the MS is marked as the gift of Thomas Ashton, which means that it came to Manchester College along with the large collection of material relating to William Shepherd, which Ashton had been bequeathed by Hannah, Shepherd's adopted daughter, the child of Jeremiah Joyce. Joyce had had a long involvement with Essex Street chapel on many levels: Lindsey had long been his friend, keen supporter and advocate, and Joyce paid homage to him in a memoir he wrote for the Monthly Magazine in December 1808. This directly draws from Hannah Lindsey's narrative, quoting it at length, and incorporating it into a larger history of Lindsey's principles, publications, and establishment of Essex Street. Joyce begins with a specific declaration of the importance of his account as a way of disseminating Nonconformist principle: while referring the interested reader to Belsham's full-length memoir, he hopes that publishing in a periodical will enable the memoir to 'come into the hands of hundreds, perhaps even thousands, in which sermons the most eloquent and captivating are never Seen'. Hannah Lindsey must have written the memoir for Joyce's use in this obituary, and it is interesting that in this context she chooses to foreground the social respectability of Lindsey, his family connections, and his good character, which by extension speak for the social position of Essex Street itself. Only a few phrases 'primitive Pastor', 'cast himself \& his wife on the Providence of God' - hint at larger struggles, theological and emotional, behind Lindsey's secession: difficulties, struggles, and evocation of past persecutions are smoothed away. In Hannah Lindsey's manuscript, and then in Jeremiah Joyce's published memoir, the identification with 
Calamy and the events of 1662 - such an important strand of Lindsey's own writing at the time - are minimised.

My closing example is one in which the identification between Lindsey and Calamy resurfaces in a way perhaps surprising, in Elizabeth Gaskell's North and South (1855). The fourth of Gaskell's novels, this in many ways marks a new maturity in her work, and a conscious effort to represent Dissenting identity and history in ways which have not been fully recognised by most recent criticism, although they were perceived by readers at the time including Charles Dickens and Charlotte Brontë. North and South takes as its starting point the secession of Mr Hale from the Church of England; the reason is not specified but it is clear that he is not experiencing a crisis of faith - 'not doubts as to religion,' Hale assures his daughter Margaret, 'not the slightest injury to that' (36) - but some aspect of difficulty with the Trinity. It is the prospect of making a 'fresh declaration of conformity' (36) in a new living which prompts Mr Hale into seceding from the Church altogether. Hale's self-questioning, then, may be aligned to Theophilus Lindsey's refusal to conform to the Thirty Nine Articles, and we might read in his narrative a refracted version of Lindsey's doubts: Gaskell's portrait of Hale may then be seen as a further move in writing the life of Rational Dissent.

The strong presence of Dissent in the novel was not universally appreciated by early readers, not least its editor, Dickens, who serialised it in Household Words between 1854-5. The serialisation was not a happy working relationship, and Dickens was particularly exercised about the doubts of Mr. Hale, which he thought caused the story to 'flag unmanageably' and were a 'difficult and dangerous subject' for fictionalisation. Gaskell, he thought, treated them at far too much length, and he urged her to aim for 'a great condensation and considerable compression' of Hale's doctrinal difficulties: 'make the scene between Margaret and her father relative to his leaving the 
church $[\ldots]$ as short as you can find it in your heart to make it' (Easson 31). Other readers also experienced uncertainties. Charlotte Brontë, like Dickens, found the subject 'difficult; at first, I groaned over it', but was then reconciled to the thought that Gaskell was not taking a position of attack on the Church, 'but of defence of those who conscientiously differ from her, and feel it a duty to leave her fold' (Easson 31 ).

'Defence of those who conscientiously differ from her': very close to Lindsey's aim in his Apology, and key to Gaskell's purpose in the novel. Indeed, Gaskell makes specific allusion to Lindsey, in a way which would have been recognised by contemporary Dissenting readers. 'I have been reading to-day of the two thousand who were ejected from their churches,' says Mr Hale as he thinks over his decision to leave the Church, and attempts to justify himself to his daughter, '[...] going to his bookcase he took down a volume, which he had often been reading lately, and from which he thought he had derived strength to enter upon the course in which he was now embarked' (36). What is that book? We are not told, but we have important clues, as $\mathrm{Mr}$ Hale reads from it, 'This is the soliloquy of one who was once a clergyman in a country parish, like me; it was written by a Mr. Oldfield, minister of Carsington, in Derbyshire', he says, and goes on to quote extensively from Calamy's excerpts of Oldfield's manuscript testimony:

Then he read aloud, -

'When thou canst no longer continue in thy work without dishonour to God, discredit to religion, forgoing thy integrity, wounding conscience, spoiling thy peace, and hazarding the loss of thy salvation... (37)

As Angus Easson first noticed, this quotation is actually Oldfield by way of Lindsey's Apology, in its 1782 fourth edition, quoted accurately and at length (Easson 35). As we have seen, Lindsey's evocation of Calamy is a very important moment in his profession 
of faith, bringing the persecutions of 1662 into play in the later eighteenth century. Now Gaskell demonstrates her knowledge of both writers and signals the role her novel plays in a larger lineage of Dissenting narrative, bringing 1662 and 1774 into dialogue with the social questions of a new industrial age. It may also have been a private homage: the person to whom Lindsey confided in 1772 that 'I never was more affected with any book than with Calamy's History' had been William Turner. Turner was an important figure for Gaskell, who had stayed with his family in Newcastle for long periods during her youth, and through whose connections she had met her husband; it would be William Gaskell who would preach Turner's funeral sermon in 1859. The evocation of Lindsey's struggles, then, functions both as a public and a private allusion to the history of Dissent Gaskell knew intimately.

But why? What purpose does she have in linking the struggles of Lindsey with those of Mr. Hale, given that Hale is ineffectual, weak, wavering about anything other than intellectual matters, too much of a 'poor coward' in his own words to break the news to his wife, and then unable fully to recognise the toll his decision has taken on his family. In some ways this seems to correspond with the frustration Gaskell herself at times expresses with Unitarian theological debate, as when she tells Charles Eliot Norton in 1859 that 'Mr Gaskell has been asked to go to be Minister in Essex St London, (Mr Lindsay's place you know - )' William Gaskell, by now well settled in Manchester, declined. 'So,' Gaskell continues 'his colleague Mr Ham goes ( $\{$ all $\}$ and we women Gaskells are none of us sorry, - oh! for some really spiritual devotional preaching instead of controversy about doctrines, - about whh I am more \& more certain we can never be certain in this world.)' (Letters 537). Rather than 'controversy about doctrines', Gaskell attempts to foreground uncertainty and doubt, seeking to prompt an emotional response through the story of Mr Hale's secession just as Calamy had done 
with his narratives of the ejected ministers.

As such, the example provided by Mr Hale gives strength to those around him, as when he tells Margaret to 'think of the early martyrs' (37). This image of conscience does eventually evoke a similar response in her, as she comes to realise the limitations of her own earlier viewpoints, and then, symbolically, to fall in love with the representative of the North, the mill-owner John Thornton. In her own way, Gaskell is continuing the message of unity and tolerance preached at Essex Street. Lindsey had hoped in that opening sermon, however uncertainly, 'to keep the unity of the Spirit in the bond of peace'; now Gaskell creates her own images of unity, as in the moment when Mr Hale and the non-believing mill-worker Nicholas Higgins somewhat implausibly debate the nature of faith, before joining in family prayer, 'Margaret the Churchwoman, her father the Dissenter, Higgins the Infidel, knelt down together. It did them no harm' (216). It may only be a brief and tentative moment of pause, but Gaskell is keen to show how alliances might be formed between opposing sides - North and South, workers and masters, male and female, unbelievers and those of different faiths. Opposition and persecution had been uneasily evoked by Lindsey's own autobiographical writing; his wife, in her biographical account of him, attempted to smooth away such difficulties. Gaskell, almost fifty years later, in her refracted portrait, deliberately acknowledges the importance of such narratives of persecution and courage to Dissenting identity. In her retelling, however, they become woven into a larger social picture, in which each of the characters must reconsider their own history, deal with their own doubts and crises of conscience, and stand up to authority in different ways. Calamy's stories of martyrdom may have had a specific resonance for Gaskell. Her fiction, like her biographical practices, may be read as self-reflexive, and her invocation of the Great Ejection bears some parallels to Josephine Butler's 'powerful 
displaced self-mythologising' analysed by Rebecca Styler elsewhere in this volume. Styler shows how the martyrdom of Catherine of Siena took on special significance to Butler as she attempted to articulate her own reforming identity. Similarly, Gaskell was at this point in her creative life struggling with her identity as a Unitarian novelist. Reactions to Ruth (1853) had discomfited her, particularly in her own religious community: two of her husband's congregation, she tells Eliza Fox, had 'burnt' its first volume, 'a third has forbidden his wife to read it; they sit next to us in Chapel and you can't think how 'improper' I feel under their eyes' (Letters 223). In the letters of early 1853, she repeatedly, like Hale contemplating exile, pleads for 'strength' and looks to a narrative of martyrdom to explain her position, comparing herself to 'St Sebastian tied to a tree to be shot at with arrows' (220-1). Yet she is convinced of the rightness of her actions and the necessity of speaking out, a position of self-imposed suffering for conscience's sake which finds an echo in Hale's exile. North and South is a profoundly personal reflection on the consequences of having 'spoken out my mind in the best way I can' (221) in Ruth: an exploration of what it means to live by one's own values of enquiry and 'plain and earnest truth' (225), even to the point of social martyrdom.

We should see Lindsey's role in the novel, then, not as a direct model for Hale himself, but rather as an informing presence throughout the whole. First, his struggles shape the ways in which Gaskell's characters should confront their own doubts and maintain a clear conscience. Secondly, Gaskell casts herself as the public voice of Rational Dissent, just as Lindsey had sought to speak for an earlier generation. Gaskell's version of Dissent, filtered through her readings of Wordsworth and Austen, is much more emotionally explicit than Lindsey's accounts or his wife's obituary memoir. As opposed to the earlier narratives, it puts difficulties and conflicts at the centre of the story. But it is, like them, a public statement of Dissent and its role in the 
larger community, an aspect which both Dickens and Brontë recognised.

Three moments then, in the life of Rational Dissent: three different ways in which Dissenting lives have been remembered. Each example continues to shape perceptions of Dissenting community. Essex Street Chapel is now Essex Hall, the headquarters of Unitarianism in the UK, from which they not only organise the wider religious community but campaign against social injustices and for equal marriage, LGBT rights, and penal reform. Meanwhile, Hannah Lindsey's manuscript has been preserved in a way in which she might have approved. The box which contains his sermons and her memoir now sits in Harris Manchester College. Originally this was the Warrington Academy, but it has now become a full Oxford college; although it retains certain differences - for example, it only takes mature students - it has been absorbed into the mainstream of Oxford University. Dissent has finally made its way into the heart of the Establishment, as Hannah Lindsey in some ways attempts to do in her biography of her husband. Finally, Gaskell's novel, with its allusions to Calamy and Lindsey, takes difficulties of faith and conscience and deliberately sets them against a wider backdrop of social and national questions: the collective concerns and life writings of a specific community might thus make their way into a larger literary dialogue.

The author wishes to acknowledge the help of the librarians of Harris Manchester College, Oxford; Emrys Jones and Andrew King, who kindly invited me to give a talk at the University of Greenwich seminar, "Community and its Limits"; Jeremy Davies, David Higgins and the participants in the Creative Communities network and the 'Community and its Limits, 17451832', University of Leeds; David Wykes and the participants in the Seminar in Dissenting Studies at Dr Williams's Library. 
Notes

1. The Corporation Act, which excluded Catholics, Protestant Dissenters, and Jews from membership of town corporations was introduced in 1661, the Test Act, which excluded the same groups from civil or military posts, in 1673; it was not until 1829 that the Catholic Emancipation Act was passed, and Jewish emancipation did not take place fully until 1890 . It is important to remember that there could be deep division among Dissent - Methodists, for example, viewed themselves as very different from Unitarians - and between Catholics, Jews, and Dissenters.

2. See also G. M. Ditchfield, 'The Revd William Chambers, DD (c.1724-1777)', Enlightenment and Dissent, 4 (1985), 3-12.

3. See also John McLachlan, 'Theophilus and Hannah Lindsey: Two Hundred Years Later', Transactions of the Unitarian Historical Society, XV (1974), 117-29.

\section{References}

Achinstein, Sharon. Literature and Dissent in Milton's England. Cambridge:

Cambridge University Press, 2003.

Appleby, David J. Black Bartholomew's Day: Preaching, Polemic and Restoration Nonconformity. Manchester: Manchester University Press, 2007.

Barthes, Roland. 'The Death of the Author', in Authorship, From Plato to the Postmodern. A Reader. Edited by Sean Burke. Edinburgh: Edinburgh University Press, 1995.

Baxter, Richard and Edmund Calamy. An abridgement of Mr. Baxter's History of his life and times. With an account of the ministers, \&c. who were ejected after the Restauration. 2 vols. London, 1713.

Baxter, Richard. Reliquiae Baxterianae: Or, Mr. Richard Baxter's Narrative of the Most Memorable Passages of His Life and Times. ed. Matthew Sylvester. London: 1696. 
Belsham, Thomas. Memoirs of the Late Reverend Theophilus Lindsey. London:

Williams and Norgate, 1873.

Calamy, Edmund. An Historical Account of My Own Life: With Some Reflections on the Times I Have Lived In (1671-1731), edited by John Towill Rutt. 2 vols. London: Colburn and Bentley, 1830.

Cappe, Catharine. Memoirs of the Life of the Late Mrs. Catharine Cappe. London: Longman, Hurst, Rees, Orme and Brown, 1822.

Ditchfield, G. M. "Hannah Lindsey and her Circle: the Female Element in Early British Unitarianism", Enlightenment and Dissent, 26 (2010): 54-79.

Easson, Angus. “Mr Hale's Doubts in North and South”, RES, 31.121 (1980): 30-40.

Gaskell, Elizabeth. North and South, edited by Elisabeth Jay. London: Pickering and Chatto, 2005.

Gaskell, Elizabeth. The Letters of Mrs Gaskell, edited by J. A. V. Chapple and Arthur Pollard. Manchester: Manchester University Press, 1966.

Haakonssen, Knud. Enlightenment and Religion: Rational Dissent in EighteenthCentury Britain. Cambridge: Cambridge University Press, 1996.

Lindsey, Hannah. 'MS Account of the Early Life of Theophilus Lindsey', MS. Lindsey 2. Harris Manchester College, Oxford, 1808.

Lindsey, Theophilus. A Discourse Addressed to the Congregation at the Chapel in Essex Street, Strand, on Resigning the Pastoral Office among Them. London: Johnson, 1793.

Lindsey, Theophilus. A Sermon Preached at the Opening of the Chapel in Essex-House, Essex-Street [...] On Sunday, April 17, 1774. London: Johnson, 1774.

Matthews, A. G. Calamy Revised; being a revision of Edmund Calamy's Account of the ministers and others ejected and silenced, 1660-2. Oxford: Oxford University Press, 1934. 
Seed, John. Dissenting Histories. Religious Division and the Politics of Memory in Eighteenth-Century England. Edinburgh: Edinburgh University Press, 2008. 
